\title{
Basement and crustal structure of the Davis Sea region (East Antarctica): implications for tectonic setting and continent to oceanic boundary definition
}

\author{
Y. B. Guseva, ${ }^{1}$ G. L. Leitchenkov, ${ }^{2}$ V. V. Gandyukhin, ${ }^{1}$ and S. V. Ivanov ${ }^{1}$ \\ ${ }^{1}$ Polar Marine Geosurvey Expedition, 24, Pobedy St., 189510, Lomonosov, St.-Petersburg, Russia (antarctida@peterlink.ru) \\ ${ }^{2}$ Institute for Geology and Mineral Resources of the World Ocean, 1, Angliysky Ave. 190121, St.-Petersburg, Russia (german_1@mail.ru)
}

\begin{abstract}
This study is based on about $8400 \mathrm{~km}$ of MCS, magnetic and gravity data as well as 20 sonobuoys collected by the Russian Antarctic Expedition during 2003 and 2004 in the Davis Sea and adjacent areas between $80^{\circ} \mathrm{E}$ and $102^{\circ} \mathrm{E}$. Major tectonic provinces and features are identified and mapped in the study region including: 1) A marginal rift with a the extended continental crust ranging 130 to more than $200 \mathrm{~km}$ in width; 2) The marginal volcanic plateau of the Bruce Bank consisting of the Early Cretaceous igneous rocks; 3) The Early Cretaceous and Late Cretaceous-Paleogene oceanic basins; and 4) The Early Cretaceous igneous province of the Kerguelen Plateau. Four major horizons identified in the sedimentary cover of the Davis Sea region are attributed to main tectonic events and/or paleoenvironmental changes.

Citation: Guseva Yu.B., G.L. Leitchenkov, and V.V. Gandyukhin (2007), Basement and crustal structure of the Davis Sea region (East Antarctica): implications for tectonic setting and continent to ocean boundary definition, in Antarctica: A Keystone in a Changing World - Online Proceedings of the $10^{\text {th }}$ ISAES, edited by A. K. Cooper and C. R. Raymond et al., USGS Open-File Report 2007-1047, Short Research Paper 025, 4 p. doi:10.3133/of2007-1047.srp025.
\end{abstract}

\section{Introduction}

The Davis Sea (DS) is located on the Wilhelm II and western Queen Mary Land margins and is bounded by seabed elevations of the southern Kerguelen Plateau (SKP) on the north-west and the Bruce Bank (BB) on the east. On the west, the DS is linked through the bottle-neck of the Princess Elizabeth Trough to the Cooperation Sea whereas to the north, it passes into the deep water areas of the southern Labuan Basin and the Australian-Antarctic Basin (Fig. 1). About $8400 \mathrm{~km}$ of MCS, gravity and magnetic data as well as 20 sonobuoys were acquired in the DS during 2003 and 2004 cruises of RV "Akademik A. Karpinsky" (Fig. 1).

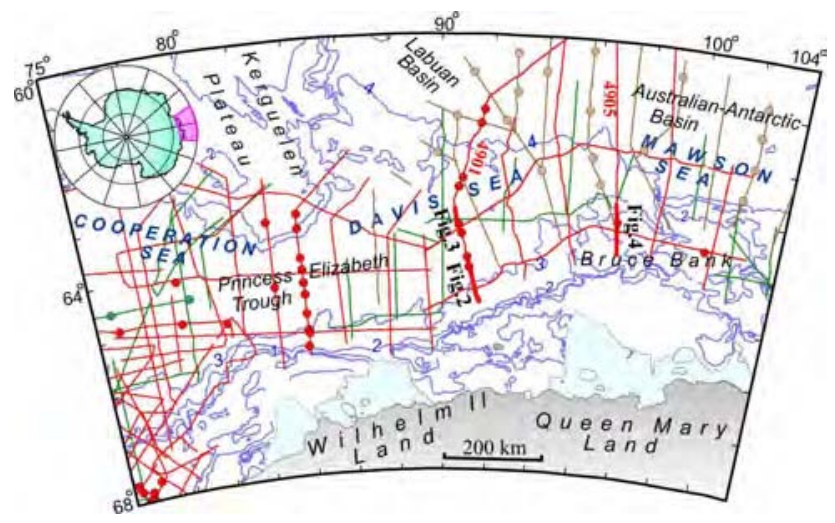

Figure 1. Geophysical studies in the Davis Sea region. Profiles (lines) and sonobuoys (circles) are colored in accordance with national contributions: red color stands for Russian, brown for Australian and green for Japanese cruises. Bold line segments show locations of illustrated seismic profiles; numbers refer to figure numbers.

Earlier, in 1999 and 2001, this region was investigated during the Japanese and Australian expeditions (Murakami et al., 2000; Stagg et al., 2004) which acquired about $5500 \mathrm{~km}$ of MCS lines and potential field data. In spite of the extensive database of available geophysical data, many aspects of the DS crustal structure and evolution remain poorly understood. This paper is based on the interpretation of all available geophysical data from the DS and focuses on the tectonic structure and evolution of this part of the Antarctic margin.

\section{Crustal structure and seismic stratigraphy}

Several types of acoustic basement are identified in the DS region based on its depth, surface morphology and reflection seismic pattern. On the western outer shelf, the basement lies at depths of 1.0-1.5 km and has a flat or slightly rough surface gently dipping northward. The basement beneath the continental slope and the upper continental rise descends abruptly to a depth of 7.0-8.0 $\mathrm{km}$ showing a fault-bounded morphology. Under most of the continental rise, the basement has a subhorizontal surface with moderately dissected topography (Fig. 2) but oceanwards (from the lower continental slope) it becomes remarkably flat, smooth and highly reflective (Fig. 3).

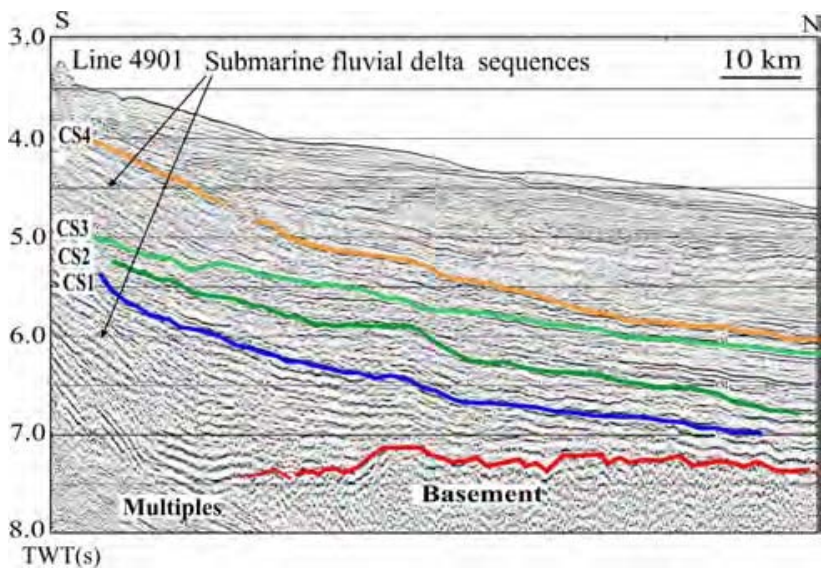

Figure 2. Seismic profile showing basement morphology beneath the continental rise and seismic stratigraphy. 


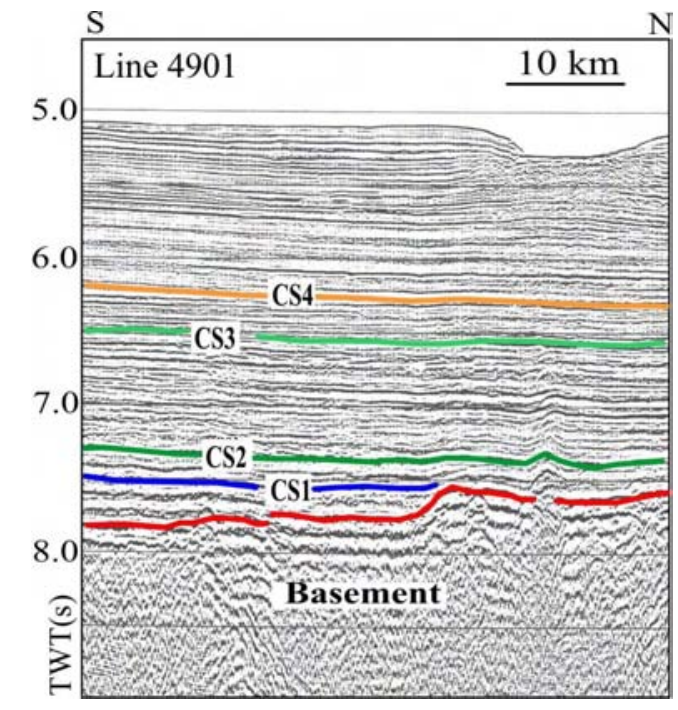

Figure 3. Seismic profile showing flat basement morphology beneath the lower continental rise and the step in the flat basement surface.

This smooth basement is complicated by the WSWENE-trending step up to $700-800 \mathrm{~m}$ high (Fig. 3) that is discernible on most of seismic lines. The step is marked by a prominent linear high-amplitude (up to $450 \mathrm{nT}$ ) magnetic anomaly. These specific features have been first recognized in the Cooperation Sea where the step and magnetic anomaly are more distinct and extensive (about $1000 \mathrm{~km}$ long). In the southern Labuan Basin, the basement is poorly studied but some northern lines suggest a moderately rugged topography.

The SKP and the BB are characterized by clear basement stratification. The SKP (delineated morphologically by $3.5-4.0 \mathrm{~km}$ isobaths) and its deeper rim are characterized by layered acoustic basement with dipping or subparallel discontinuous internal reflectors topped by a generally smooth and distinct surface, locally complicated by scarps and isolated or linear highs and depressions. The basement surface descends gently from the central shallowest $(2.0-2.5 \mathrm{~km})$ part of SKP basinwards to depths of $4.0-5.0 \mathrm{~km}$ and then steepens to form a plateau slope generally coinciding with the conventional morphological boundary of SKP. The layered basement structure is recorded down to the foot of the SKP slope and further south-eastward. (Stagg et al., in press). The SKP shows a high-amplitude (up to $700 \mathrm{nT}$ ) mosaic magnetic field with slightly elongated anomalies, mainly sub-latitudinal, distinctly traced across the northwestern DS and the southern Labuan Basin.

The BB consists of two basement blocks divided by a narrow, NNW-SSE oriented fault-bounded depression about $40 \mathrm{~km}$ wide. The basement of the western block lies at depths of $3.5-5.0 \mathrm{~km}$ and demonstrates an acoustically strong surface and a package of seaward-dipping reflectors below it (Fig. 4). The basement of the eastern block is shallower, at a depth less than $2.0 \mathrm{~km}$. Beneath the surface, its acoustic pattern exhibits subparallel, discontinuous and locally contorted reflectors. Both blocks are marked by intense (up to $450 \mathrm{nT}$ ) positive magnetic anomalies. The Australian-Antarctic Basin displays highly rugged basement topography with a local relief up to $2.5 \mathrm{~km}$ high. Individual basement highs recorded by MCS lines are well expressed spatially by satellite derived gravity anomalies (Sandwell and Smith, 1997) and aligned in WNW-ESE direction.

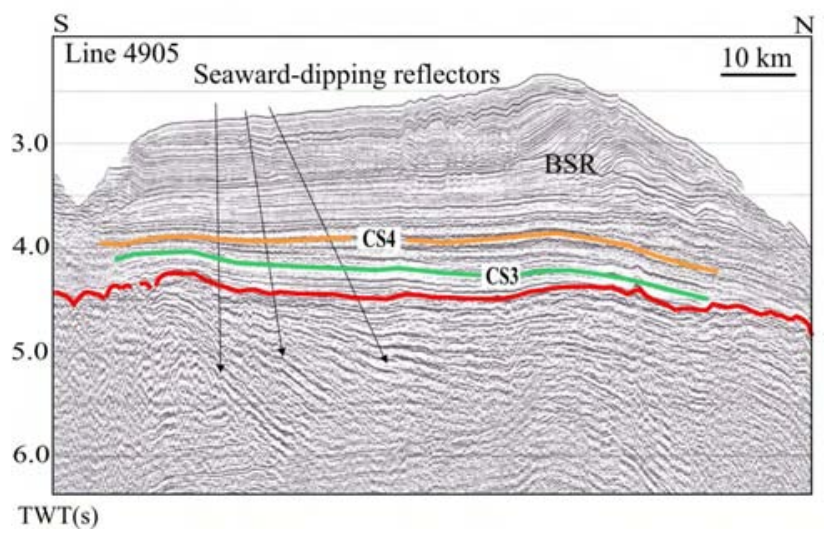

Figure 4. Seismic profile showing basement pattern with seaward dipping reflectors on the Bruce Bank.

The crustal thickness inferred from sonobuoy data and gravity modeling ranges from $25 \mathrm{~km}$ under the outer shelf to $15-22 \mathrm{~km}$ under the continental slope. It amounts to 6-8 $\mathrm{km}$ under the continental rise and the abyssal plains; slightly increasing in the western DS where dipping reflector sequences are recorded. The SKP and the BB are characterized by crustal thickness of $18-20 \mathrm{~km}$. A magnetic lineation in the DS region is rather poor and the existing anomaly identifications suggested by Murakami et al. (2000) and Stagg et al. (in press) seem to be very controversial, despite the additional magnetic data available.

Four major horizons (named from CS1 to CS4 from the oldest to the youngest) have been identified in the DS using the nomenclature applied earlier on the Enderby Land margin (Fig. 2, 3 and 4). The lower CS1 horizon is reliably recognized mainly as an acoustically distinct boundary onlapping the basement along the regional step or slightly landward. Horizon CS2 onlaps the smooth and flat basement not far (oceanward) from the basement step whereas onlaps of overlying horizons are mapped along the slope of the SKP (CS3 and CS4) and in the landward part of the Australian-Antarctic Basin (CS3). Three seismic sequences below horizon CS4 show similar and mainly parallel-bedded reflection patterns. Beneath the upper continental rise of the central DS, the sequences between CS1 and CS2 as well as between CS3 and CS4 show sigmoid reflectors and clinoforms typical of marginal delta sequences (Fig. 2). Horizon CS4 marks a change in seismic patterns connected with the development of channel-levee systems and sediment 
waves above it, although in the western DS and in the Princess Elizabeth Trough, channels are subdued or absent. The total thickness of the sedimentary cover amounts to $5.0-6.0 \mathrm{~km}$ beneath the continental rise of the DS, 2.0-1.5 km in the southern Labuan Basin and the Australian-Antarctic Basin, and a few hundreds of meters on the SKP and the BB.

\section{Discussion}

The DS has resulted from rifting and the break-up between Greater India and the Australian-Antarctic continent in Late Mesozoic time (Lawver et al., 1992). In the Early Cretaceous its lithosphere was affected by the Kerguelen plume emplacement that culminated in prolific volcanic eruption at c. 120 Ma ago (Coffin et al., 2002). In the Late Cretaceous a new plate boundary between Australia and Antarctica dissected the young Indian Ocean north-east of the DS (Lawver et al., 1992).

The shallow-sited basement under the shelf is interpreted by us as the unstretched continental crust of the Antarctic Precambrian Shield whereas the descending faulted basement and the deeply submerged basement below the continental slope and the rise represent the stretched continental crust of the marginal rift, with discernible rift flank and rift bottom lineaments (Fig. 5).

The boundary between the stretched continental and oceanic crust (continent-to-ocean boundary, COB) in the study region is inferred from different structural and geophysical characteristics based on information gained during previous studies on the East Antarctic margin. One of these characteristics (derived from more than 100 sonobuoys collected between $7^{\circ} \mathrm{E}$ and $100^{\circ} \mathrm{E}$ ) is refraction velocities showing a clear change at the basement surface from 5.8-6.2 $\mathrm{km} / \mathrm{s}$ (beneath the upper and middle continental rise) to $4.8-5.6 \mathrm{~km} / \mathrm{s}$ (beneath the lower continental rise and the abyssal plane) which are typical for the continental and oceanic crust (layer 2B), respectively (Fig. 5). In the DS and in the Cooperation Sea, this change is recorded across the regional basement step (Fig. 3 and 5) and high-amplitude linear anomaly that are thought to mark the COB.

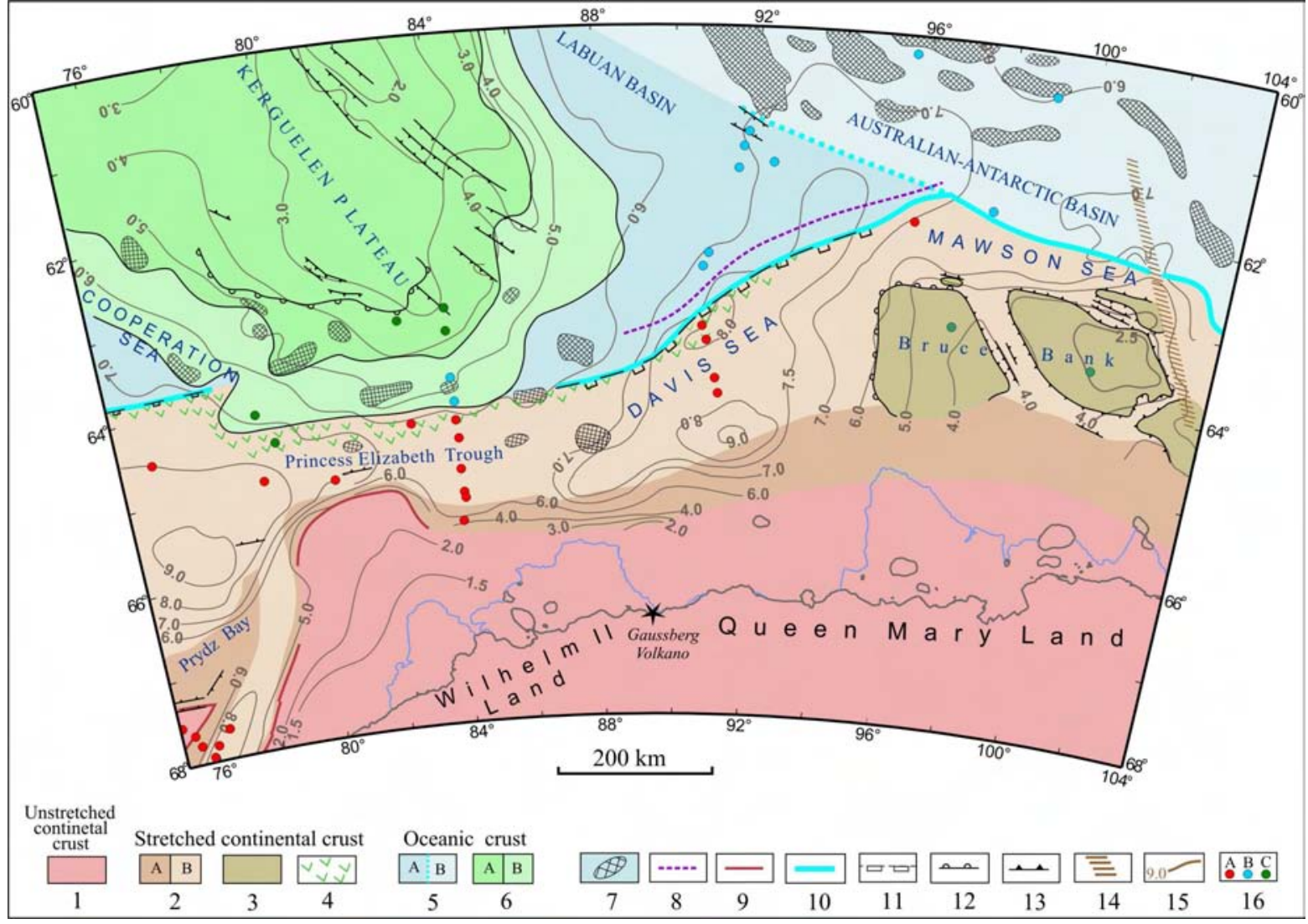

Figure 5. Tectonic provinces and structural features of the Davis Sea region. 1 - Precambrian East Antarctic Shield; 2 - late Jurassic marginal rift graben (A - rift flank, B - rift bottom); 3 - Early Cretaceous marginal volcanic plateau; 4 - Early Cretaceous breakup-related lava flows; 5 - spreading basin (A - Early Cretaceous, B - Late Cretaceous Paleogene); 6 - Late Cretaceous large igneous province with thickened (A - up to $20 \mathrm{~km}$ and B - 9-11 km) magmatic crust; 7 - isolated basement highs/ridges; 8 - axis of linear high-amplitude magnetic anomaly; 9 - inboard rift boundary; 10 - COB; 11 - step at the basement surface; 12 - volcanic escarpments; 13 - normal and other faults; 14 - fracture zone; 15 - depth to basement (in $\mathrm{km}) ; 16$ - refraction velocities at the basement surface $(\mathrm{A}-5.8-6.2 \mathrm{~km} / \mathrm{s}$; $\mathrm{B}-4.8-5.6 \mathrm{~km} / \mathrm{s} ; \mathrm{C}-4.5-5.2 \mathrm{~km} / \mathrm{s})$. 
The magnetic anomaly is likely to be caused by the difference between the weakly magnetized continental crust and strongly magnetized oceanic crust. Very similar crustal signatures are recorded in the Cooperation Sea where the COB definition is defined by MCS data (Stagg et al., 2005). Northward of the BB, the COB is defined by a transition from the basement with moderately rough to the highly rugged basement topography (Fig. 5). The $\mathrm{COB}$ in the Princess Elizabeth Trough is fairly ambiguous.

A seismic reflection pattern of the BB acoustic basement with dipping or parallel reflectors is typical for volcanic units reported elsewhere including the Antarctic margin (e.g. Hinz et al., 2005; White and McKenzie, 1989). The thickness of this unit according to MCS and sonobuoy data is about $2 \mathrm{~km}$. The pre-breakup Gondwana reconstructions show that the $\mathrm{BB}$ was conjugate to the Naturaliste Plateau which is also capped by volcanic rocks (Coffin et al., 2002). We interpret the emplacement of igneous rocks in both areas as an initial output of the Kerguelen hotspot that can be dated at 130-132 Ma predicted on the age of presumably contemporaneous Bunbury basalts in south-western Australia (Coffin et al., 2002). If this is the case, a marginal igneous activity is correlated with the incipient sea-floor spreading between India and Australia-Antarctica.

The nature of the smooth and flat basement oceanward of the proposed COB is difficult to explain, however it is a characteristic feature of many regions where the oceanic crust is formed close to Large Igneous Provinces (e.g. Hinz et al., 2005; White and McKenzie, 1989). Landward of the COB, the smooth basement appears to be represented by basalt lava flows overlying syn-rift sediments (Fig. 3 and 5). The thicker oceanic crust with dipping basement reflectors (Stagg et al., in press) and high-amplitude mosaic magnetic anomalies in the western DS suggest excessive melt production resulted from hotspot-ridge interaction. The Late Cretaceous plate boundary dissecting the Early Cretaceous crust of the DS is recognized as a transition from smooth to highly rugged basement types (Fig. 5). The basement highs mapped by the satellite derived gravity (Sandwell and Smith, 1997) north-east of this plate boundary appear to represent a conjugate part of the Diamantina Zone.

The seismic stratigraphy model is based on continuous correlation of identified horizons over an extensive region of the East Antarctic margin (Leitchenkov et al., this volume). The lower horizon (CS1) is interpreted to correspond with the continental break-up between India and Antarctica in the Early Cretaceous (Lawver et al., 1992). Based on the interrelation between the magneticanomaly dated oceanic crust on the East Antarctic margin and basement onlaps of recognized horizons, CS2 and CS3 are considered to be not older than the middle Early Cretaceous and the Early Eocene, respectively. The change in the seismic reflection pattern across CS4 is thought to be correlated with a continental scale glaciation at about $34 \mathrm{Ma}$ ago (Leitchenkov et al., this volume).

\section{Summary}

Several types of acoustic basement are recognized in the DS region and these correspond to different tectonic provinces including 1) unstretched continental crust; 2) marginal rift up to $200 \mathrm{~km}$ wide with a marginal volcanic plateau of the BB; 3) thickened igneous crust of the SKP; and 4) oceanic crust. Different geophysical and structural criteria allow identification of the COB. Magnetic anomalies are actually not identifiable to help to decode the early history of sea-floor spreading. Four major horizons (labeled from CS1 to CS4) are identified in the sedimentary cover. CS1 is interpreted to correlate with the continental break-up in the Early Cretaceous; CS2 and CS3 are thought to be not older than the Middle Early Cretaceous and the Early Eocene, respectively; and CS4 corresponds with the onset of continental scale Antarctic glaciation at the Eocene/Oligocene boundary.

Acknowledgments. We are grateful to Mike Coffin, John Gamble and anonymous reviewer for valuable comments and constructive suggestions which helped to improve this manuscript. Funding for this work was partly provided by Federal Target Program "World Ocean" (Subprogram "Antarctica", Project 13).

\section{References}

Coffin, M.F., M.S. Pringle, R.A. Duncan, T.P. Gladczenko, M. Storey, R.D. Muller, and L.A. Gahagan (2002), Kerguelen hotspot magma output since 130 Ma, J. Petrology, 43, 1121-1139.

Hinz, K., S. Neben, Y.B. Gouseva and G.A. Kudryavtsev (2005), A Compilation of Geophysical Data from the Lazarev Sea and the Riiser-Larsen Sea, Antarctica, J. Mar. Geoph. Res., 25, 233-245.

Lawver, L.A., L.M. Gahagan, and M.F. Coffin (1992), The development of paleoseaways around Antarctica, in The role of the Southern Ocean and Antarctica in global change: an Ocean Drilling Perspective, edited by J.P. Kennet, and J. Barren, Ant. Res. Ser., AGU, 56, 7 - 30.

Leitchenkov, G.L., Y.B. Guseva, and V. V. Gandyukhin (2007), Cenozoic environmental changes along the East Antarctic continental margin inferred from regional seismic stratigraphy, this volume.

Murakami, F., T. Ishihara, H. Odo, M. Fujimoto, H. Oda, K. Sugiyama, and M. Joshima (2000), Preliminary report on geological and geophysical survey results in the Princess Elizabeth Trough and its vicinity by R/V Hakurei-maru, Polar Geoscience, 13, 165-186.

Stagg, H.M.J., J.B. Colwell, N.G Direen., P.E. O'Brien, G. Bernardel, I. Borissova, B.J. Brown, and T. Ishihara, (2005), Geology of the continental margin of Enderby and Mac. Robertson Lands, East Antarctica: insights from a new dataset, in East-west Antarctic tectonics and Gondwana break-up $60 \mathrm{~W}$ to $60 \mathrm{E}$, edited by W. Jokat, Mar. Geoph. Res., 25, 3-4, 183-219.

Stagg, H.M.J., J.B. Colwell, I. Borissova, T. Ishihara, and G. Bernardel (2007), The Bruce Rise area, East Antarctica: formation of a continental margin near the Greater India - Australia - Antarctica triple junction, Terra Antarctica, in press.

Sandwell, D.T., and W.H.F. Smith (1997), Marine gravity anomaly from Geosat and ERS-1 satellite altimetry, J. Geoph. Res., 102, 1003910054.

White, R.S., and D.P. McKenzie (1989), Magmatism at rift zones: The generation of volcanic continental margins and flood basalts, Journ Geoph. Res., 94, 7685-772. 